\title{
Spectral Effects of Supplemental Greenhouse Radiation on Growth and Flowering of Annual Bedding Plants and Vegetable Transplants
}

\author{
Brian R. Poel ${ }^{1}$ and Erik S. Runkle ${ }^{2,3}$ \\ Department of Horticulture, Michigan State University, 1066 Bogue Street, \\ East Lansing, MI 48824
}

Additional index words. controlled environments, LEDs, light-emitting diodes, light quality, plant quality, seedlings

\begin{abstract}
Supplemental radiation (SR), traditionally provided by high-pressure sodium (HPS) lamps, is recommended for greenhouse production of seedlings during radiationlimiting conditions. Light-emitting diodes (LEDs) have emerged as an appealing alternative to HPS lamps primarily because they can provide SR at improved energy efficiencies, they have longer fixture lifetimes, and the radiation spectrum can be tailored to potentially manipulate plant morphology by targeting radiation absorption of specific photoreceptors. We grew seedlings of three annual bedding plants and two vegetable transplants in greenhouses at $20^{\circ} \mathrm{C}$ under a 16-h photoperiod under six SR treatments: five that delivered a photosynthetic photon flux density $(P P F D)$ of $90 \mu \mathrm{mol} \cdot \mathrm{m}^{-2} \cdot \mathrm{s}^{-1}$ from HPS lamps $\left(\right.$ HPS $\left._{90}\right)$ or LEDs [four treatments composed of blue $(B ; 400-500 \mathrm{~nm})$, red $(R$; 600-700 $\mathrm{nm}$ ), far red (FR; 700-800 $\mathrm{nm}$ ), and/or white LEDs] and one that delivered $10 \mu \mathrm{mol} \cdot \mathrm{m}^{-2} \cdot \mathrm{s}^{-1}$ from HPS $\left(\mathrm{HPS}_{10}\right)$ lamps as a control with matching photoperiod. The LED treatments, defined by the percentages of $B$, green $(G ; 500-600 \mathrm{~nm})$, and $R$ radiation, were $B_{10} R_{90}, B_{45} R_{55}, B_{10} G_{5} R_{85}$, and $B_{12} G_{20} R_{68}+F R\left(F R\right.$ at $\left.12 \mu \mathrm{mol} \cdot \mathrm{m}^{-2} \cdot \mathrm{s}^{-1}\right)$. At transplant, leaf area and seedling height were similar among $90 \mu \mathrm{mol} \cdot \mathrm{m}^{-2} \cdot \mathrm{s}^{-1}$ treatments in all species except snapdragon (Antirrhinum majus), in which seedlings grown under $B_{12} G_{20} R_{68}+F R$ had $62 \%$ greater leaf area than those grown under $B_{45} R_{55}$ and were $47 \%, 18 \%, 38 \%$, and $62 \%$ taller than those grown under $H P S_{90}, B_{10} R_{90}, B_{10} G_{5} R_{85}$, and $B_{45} R_{55}$, respectively. After transplant and finishing under the same SR treatments, snapdragon flowered on average 7 days earlier under the $B_{12} G_{20} R_{68}+F R$ treatment than the other LED treatments, whereas geranium (Pelargonium $\times$ hortorum) grown under $B_{45} R_{55}$ and $B_{12} G_{20} R_{68}+F R$ flowered 7 to 9 days earlier than those under the $B_{10}$ $G_{5} R_{85}$ and $B_{10} R_{90}$ treatments. Seedlings of each species grown under the $H_{P S}$ treatment accumulated less dry weight and took longer to flower compared with seedlings under the other SR treatments. We conclude that radiation quality of SR has relatively little effect on seedling growth and subsequent flowering although in some crops, flowering may be earlier when SR includes FR radiation.
\end{abstract}

The photosynthetic daily light integral (DLI) is the cumulative quantity of photons within the photosynthetically active waveband (400-700 $\mathrm{nm})$ incident on a square meter during a $24-\mathrm{h}$ period and is usually

Received for publication 19 May 2017. Accepted for publication 13 July 2017.

This work was supported by the USDA National Institute of Food and Agriculture, Hatch project 192266.

We gratefully acknowledge support by the USDA National Institute of Food and Agriculture's Specialty Crop Research Initiative, the USDA-ARS Floriculture and Nursery Research Initiative, C. Raker and Sons for donation of plant material, Philips for donation of LED fixtures, and Nate DuRussel for technical assistance. We also thank Jennifer Boldt and Ryan Warner for their critical review of this manuscript.

${ }^{1}$ Former Graduate Student.

${ }^{2}$ Professor and Floriculture Extension Specialist. ${ }^{3}$ Corresponding author. E-mail: runkleer@msu. edu. expressed as moles per square meter and day. During commercial seedling production, a minimum DLI of $10-12 \mathrm{~mol} \cdot \mathrm{m}^{-2} \cdot \mathrm{d}^{-1}$ has been recommended to achieve suitable seedling quality and reduced time to flower after transplant (Lopez and Runkle, 2008; Pramuk and Runkle, 2005). Commercial production of annual (bedding plant and vegetable) seedlings primarily occurs during the winter and early spring, and in the northern United States, the mean outdoor DLI is as low as 5$10 \mathrm{~mol} \cdot \mathrm{m}^{-2} \cdot \mathrm{d}^{-1}$ (Korczynski et al., 2002); inside a greenhouse, values are typically $30 \%$ to $50 \%$ lower. Therefore, SR from electric lamps is commonly used by commercial growers to increase the DLI to increase root and shoot growth. Supplemental radiation is typically delivered by conventional high-intensity discharge lamps, most commonly from HPS lamps, and usually operates during cloudy conditions and at night. Light-emitting diodes have increasing potential to be used for SR applications as the technology develops, particularly as their intensity and efficacy increase and costs decrease (Bourget, 2008; Wallace and Both, 2016).

Unlike conventional lamps and excluding LEDs coated with phosphors, LEDs emit narrow wavebands based on their chip composition and can therefore emit specific wavebands of interest for a range of plant applications (Mitchell et al., 2015). Early focus of LED use in horticulture was on the application of $\mathrm{R}(600-700 \mathrm{~nm})$ radiation because it is strongly absorbed by chlorophyll extracts and was the first color to become feasible for horticultural radiation (Bula et al., 1991). Growth under R radiation alone in sole-source radiation (SSR) experiments produced plants with elongated hypocotyls and petioles or decreased chlorophyll development, which could be alleviated with the addition of a relatively low flux of $B$ (400-500 nm) radiation (Hoenecke et al., 1992; Tripathy and Brown, 1995). Unlike broad-spectrum radiation sources, the LED spectral output can be tailored to emit only or mostly photosynthetic or photomorphogenic radiation (Morrow, 2008).

Plant growth and development are controlled by photoreceptors that regulate hypocotyl and internode extension, leaf expansion, chlorophyll orientation, and flowering in response to specific wavebands of radiation. For example, the cryptochrome receptors, cry1 and cry2, respond to wavelengths from 390 to $480 \mathrm{~nm}$ and regulate stem extension, guard cell opening, anthocyanin accumulation, and, in at least some species, flower induction (Ahmad et al., 2002). In Arabidopsis, cryptochromes mediate hypocotyl elongation through $\mathrm{B}$ radiation regulation of gibberellic acid metabolism (Zhao et al., 2007). Phytochrome, a family of proteins that primarily absorb R and FR (700-800 $\mathrm{nm}$ ) radiation, signals shade avoidance and flowering control through gene-regulated control of transcription networks (Folta and Carvalho, 2015). Phytochrome exists in R-absorbing (inactive) and FR-absorbing (active) forms, and the incident radiation quality (particularly the R:FR) establishes a phytochrome photoequilibrium (PPE). In conditions depleted of $\mathrm{R}$ radiation, such as under a plant canopy, the PPE becomes low, which signals stem and petiole elongation (Franklin and Whitelam, 2005). With the narrow emission spectra of LEDs, one can target these photoreceptors to potentially control plant morphology, which can influence quality attributes important for commercial production of ornamental and vegetable seedlings.

Early plant experiments with $\mathrm{R}$ and FR LEDs and $\mathrm{B}$ radiation from blue fluorescent lamps showed that including B or FR radiation in SSR studies could affect plant morphology, increase plant growth, or both. Brown et al. (1995) grew 21-d-old pepper (Capsicum annuum 'Hungarian Wax') seedlings under SSR from metal halide lamps, only $\mathrm{R}$ radiation from R LEDs (peak $=660 \mathrm{~nm}$ ), $1 \%$ blue fluorescent $+99 \%$ R LEDs, and R LEDs $+59 \mu \mathrm{mol} \cdot \mathrm{m}^{-2} \cdot \mathrm{s}^{-1}$ from FR LEDs $($ peak $=735 \mathrm{~nm})$, each providing a $P P F D$ 
of $300 \mu \mathrm{mol} \cdot \mathrm{m}^{-2} \cdot \mathrm{s}^{-1}$ for $12 \mathrm{~h} \cdot \mathrm{d}^{-1}$. Plants grown under $\mathrm{R}+\mathrm{B}$ from fluorescent lamps were shorter than those grown under $\mathrm{R}$ radiation alone, whereas those grown under $\mathrm{R}+\mathrm{FR}$ radiation were tallest. Plants grown without $\mathrm{B}$ radiation had negatively affected leaf expansion and dry weight accumulation. In wheat (Triticum aestivum) grown under R LEDs (peak $=660 \mathrm{~nm}$ ) at $350 \mu \mathrm{mol} \cdot \mathrm{m}^{-2} \cdot \mathrm{s}^{-1}$ for $24 \mathrm{~h} \cdot \mathrm{d}^{-1}$, adding $10 \% \mathrm{~B}$ radiation increased plant growth and seed quantity, resulting in plants that were comparable with those grown under white fluorescent lamps (Goins et al., 1997).

Far red LEDs have been used in plant applications to manipulate extension growth of leaves and stems, as well as regulate flowering of at least some long-day plants. For example, by adding FR to B and R SSR treatments from LEDs, Park and Runkle (2017) were able to increase photosynthesis in seedlings of four annual bedding plants; those grown under increasing amounts of FR radiation displayed greater leaf expansion that subsequently increased radiation capture. In addition, stem length of tomato (Solanum lycopersicum) rootstock seedlings increased from an end-of-day FR radiation treatment from LEDs (Chia and Kubota, 2010). Red + FR radiation has been provided by incandescent bulbs to promote flowering in long-day plants, and R + white + FR LEDs effectively promoted flowering while consuming less energy (Meng and Runkle, 2014). By adding FR radiation from LEDs, it is possible to accelerate flowering of some long-day plants that are FR-radiation sensitive.

High-quality seedlings suitable for shipping and transplanting should have a high dry weight per internode and be compact. Randall and Lopez (2014) reported decreases in seedling height of six ornamental species grown under $15 \% \mathrm{~B}+85 \% \mathrm{R}$ radiation from LEDs compared with those grown under HPS $\mathrm{SR}$ at a $P P F D$ of $160 \mu \mathrm{mol} \cdot \mathrm{m}^{-2} \cdot \mathrm{s}^{-1}$. However, the same species grown under $30 \% \mathrm{~B}+70 \%$ $\mathrm{R}$ LED SR had a height similar to that of those grown under $15 \% \mathrm{~B}+85 \% \mathrm{R}$ LED SR. Similarly, previous results of growing annual seedlings under LED SR treatments (with $10 \%$ to $20 \%$ B radiation) showed inconsistent or limited effects on seedling height, leaf area, and dry weight among HPS and LED treatments that delivered the same PPFD (Poel and Runkle, 2017). Providing SR with a greater percentage of $B$ radiation, the addition of FR radiation, and longer treatment periods (from seedling emergence to flowering) could lead to greater differences in growth and development. Therefore, our objective was to evaluate SR from HPS or LEDs (with increased B or added FR radiation) on seedling quality and plant performance after transplant until flowering.

\section{Materials and Methods}

Plant material. Seeds of geranium (Pelargonium $\times$ hortorum 'Pinto Premium Salmon'), pepper 'Long Red Slim Cayenne', petunia (Petunia $\times$ hybrida 'Single Dreams White'), snapdragon 'Montego Yellow', and tomato 'Supersweet' were sown into 128-cell plug trays $(2.7 \times 2.7 \mathrm{~cm} ; 12.0-\mathrm{mL}$ volume $)$ at a commercial greenhouse (C. Raker and Sons, Inc., Litchfield, MI) and delivered to the Plant Science Research Greenhouses at Michigan State University (East Lansing, MI) 4 (replication 1) or $5 \mathrm{~d}$ (replication 2) after seeds were sown. For each species, six 128-cell trays were cut in half and the 12 half trays were randomly assigned to six radiation treatments in adjacent greenhouse sections. Seedling trays of each species were placed at about the same position in each section and rotated systematically every $2 \mathrm{~d}$ to minimize positional effects within each treatment. Seedlings were irrigated as necessary with water-soluble fertilizer providing (in mg. $\mathrm{L}^{-1}$ ) $60 \mathrm{~N}, 23 \mathrm{P}, 60 \mathrm{~K}, 27.7$ $\mathrm{Ca}, 4.6 \mathrm{Mg}, 1.3 \mathrm{Fe}, 0.6 \mathrm{Mn}, 0.6 \mathrm{Zn}, 0.6 \mathrm{Cu}, 0.4$ $\mathrm{B}$, and 0.1 Mo (MSU Plug Special; GreenCare Fertilizers, Inc., Kankakee, IL).

Radiation treatments. Different SR treatments were delivered to each greenhouse section continuously for $16 \mathrm{~h} \cdot \mathrm{d}^{-1}(0600$ to $2200 \mathrm{HR})$ at a $P P F D$ of $90 \pm 10 \mu \mathrm{mol} \cdot \mathrm{m}^{-2} \cdot \mathrm{s}^{-1}$ (five sections) or $10 \pm 2 \mu \mathrm{mol} \cdot \mathrm{m}^{-2} \cdot \mathrm{s}^{-1}$ (one section) as measured at plant height in nine different horizontal positions by a portable spectroradiometer (PS-200; StellarNet Inc., Tampa, FL) (Fig. 1). Two of the SR treatments were delivered by HPS lamps using either one 150-W fixture (LU150; Acuity Lithonia Lighting, Conyers, GA) or four 400-W fixtures (LR48877; P.L. Light Systems, Beamsville, ON, Canada) to deliver a target PPFD of $10\left(\mathrm{HPS}_{10}\right)$ or $90\left(\mathrm{HPS}_{90}\right)$ $\mu \mathrm{mol} \cdot \mathrm{m}^{-2} \cdot \mathrm{s}^{-1}$, respectively. The four remaining SR treatments were delivered by commercial 200-W LED fixtures that contained $\mathrm{R}$ $($ peak $=660 \mathrm{~nm}), B($ peak $=453 \mathrm{~nm})$, white (which was the source of $\mathrm{G}$ radiation), or FR (peak $=737 \mathrm{~nm}$ ) LEDs, three of which were wrapped in a layer of flexible, neutral-density mesh (general-purpose aluminum; New York Wire, Grand Island, NY) to reduce radiation intensity by $\approx 35 \%$ without affecting SR spectral output or incident solar radiation. Each LED fixture was mounted horizontally $1.9 \mathrm{~m}$ above the bench height, and the 400 and 150-W HPS fixtures were mounted 1.3 and $2.5 \mathrm{~m}$ above the plants, respectively. Glass walls between greenhouse sections were coated with a heavy layer of whitewash to prevent radiation treatment contamination.

The four LED treatments were defined by their 100-nm waveband ratios of B, G (500$600 \mathrm{~nm}$ ), and $\mathrm{R}$ radiation (subscript values indicate the percentage of each waveband) and were $\mathrm{B}_{10} \mathrm{R}_{90}, \mathrm{~B}_{45} \mathrm{R}_{55}, \mathrm{~B}_{10} \mathrm{G}_{5} \mathrm{R}_{85}$, and $\mathrm{B}_{12} \mathrm{G}_{20} \mathrm{R}_{68}+\mathrm{FR}$. The $\mathrm{B}_{10} \mathrm{R}_{90}$ and $\mathrm{B}_{10} \mathrm{G}_{5} \mathrm{R}_{85}$ treatments were delivered by top-lighting fixtures (GP-TOPlight DR/B-LB2013 and GP-TOPlight DR/W-MB2013; Philips, Eindhoven, the Netherlands). The $\mathrm{B}_{45} \mathrm{R}_{55}$ treatment was delivered by top-lighting fixtures providing $20 \% \mathrm{~B}+80 \% \mathrm{R}$ radiation (GP-TOPlight DR/B-HB2013; Philips) with two layers of neutral-density mesh to reduce radiation intensity (by $\approx 57 \%$ ), along with 18 B-emitting LED research modules (GreenPower LED

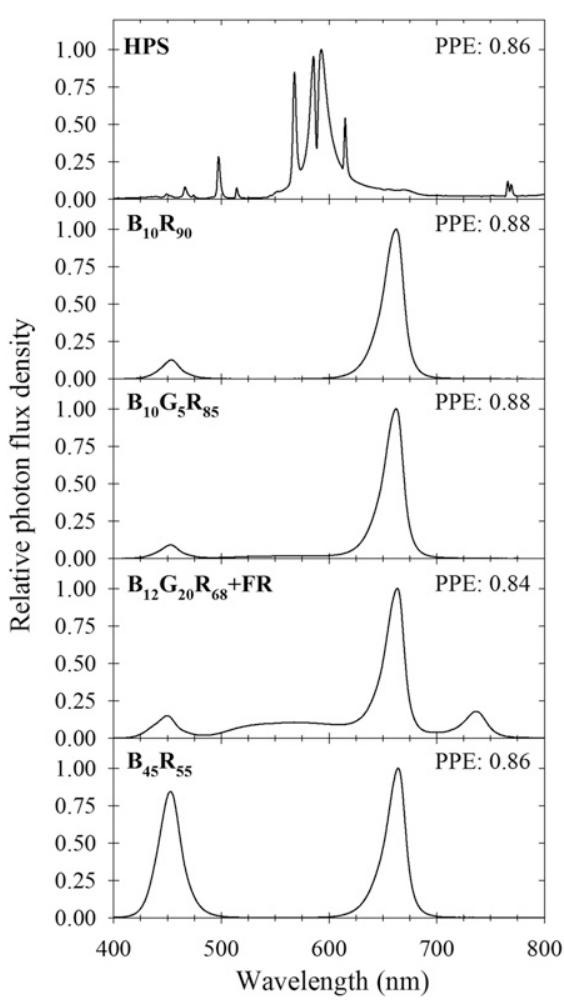

Fig. 1. The relative spectral distributions and estimated phytochrome photoequilibria (PPE) of supplemental radiation treatments between 400 and $800 \mathrm{~nm}$ from high-pressure sodium (HPS) and light-emitting diodes delivering different percentages (denoted in subscript) of blue $(B ; 400-500 \mathrm{~nm})$, green $(\mathrm{G} ; 500-600 \mathrm{~nm})$, red $(\mathrm{R} ; 600-700 \mathrm{~nm})$, and far red $(\mathrm{FR} ; 700$ $800 \mathrm{~nm}$ ) radiation.

research module blue; Philips) hung $60 \mathrm{~cm}$ above the benches to provide the target $P P F D$. The fourth LED treatment, $\mathrm{B}_{12} \mathrm{G}_{20} \mathrm{R}_{68}+\mathrm{FR}$, was provided by top-lighting fixtures that emitted FR radiation at $12 \mu \mathrm{mol} \cdot \mathrm{m}^{-2} \cdot \mathrm{s}^{-1}$ (GPTOPlight DR/W/FR_2-HB2013; Philips) and did not require mesh to obtain the target $P P F D$. The estimated PPE established under each treatment was calculated with spectroradiometer software (SpectraWiz; StellarNet Inc.) that used the formula described by Sager et al. (1988) and ranged from 0.84 to 0.88 (Fig. 1).

Environmental conditions. The experiment was performed in six glass-glazed greenhouse sections oriented west to east and measuring $4.0 \mathrm{~m}$ by $4.6 \mathrm{~m}$, with a $2.2-\mathrm{m}$ high gutter and $3.5-\mathrm{m}$ peak. The set point for air temperature was $20^{\circ} \mathrm{C}$ during the day and night, and was maintained by steam heating, exhaust fans, and roof vents controlled by a greenhouse environmental control system (Integro 725; Priva North America, Vineland, ON, Canada). In each section, air temperature was recorded by an aspirated thermocouple (Type E; Omega Engineering, Stamford, CT) above canopy height. Leaf surface temperature was measured by an infrared thermocouple (Type K, OS36-01; Omega Engineering) placed $15 \mathrm{~cm}$ above one seedling tray in each section during the 
Table 1. Means ( $(\mathrm{SD})$ of temperature and photosynthetic daily light integral (DLI) as measured in greenhouses by aspirated thermocouples, infrared sensors, and quantum sensors during the seedling phase under ambient radiation, with supplemental radiation treatments delivered by high-pressure sodium (HPS) lamps or light-emitting diodes (LEDs). For the LED treatments (all delivered at $90 \mu \mathrm{mol} \cdot \mathrm{m}^{-2} \cdot \mathrm{s}^{-1}$ ), subscript values that follow each waveband of blue (B; 400-500 nm), green $(\mathrm{G} ; 500-600 \mathrm{~nm})$, red $(\mathrm{R} ; 600-700 \mathrm{~nm})$, and far red (FR; 700-800 nm) radiation indicate their percentages. Numbers in subscript after HPS treatments denote their intensity $\left(\mu \mathrm{mol} \cdot \mathrm{m}^{-2} \cdot \mathrm{s}^{-1}\right)$.

\begin{tabular}{|c|c|c|c|c|c|}
\hline Treatment initiation & $\begin{array}{l}\text { Supplemental } \\
\text { radiation treatment }\end{array}$ & Daytime air temp $\left({ }^{\circ} \mathrm{C}\right)$ & Daytime canopy temp $\left({ }^{\circ} \mathrm{C}\right)$ & Air-canopy temp $\left({ }^{\circ} \mathrm{C}\right)$ & $\operatorname{DLI}\left(\mathrm{mol} \cdot \mathrm{m}^{-2} \cdot \mathrm{d}^{-1}\right)$ \\
\hline \multirow[t]{6}{*}{4 Nov. } & $\mathrm{HPS}_{10}$ & $19.2 \pm 0.9$ & $14.0 \pm 2.6$ & 5.2 & $3.8 \pm 1.7$ \\
\hline & $\mathrm{HPS}_{90}$ & $19.5 \pm 1.2$ & $17.2 \pm 3.3$ & 2.3 & $7.0 \pm 1.7$ \\
\hline & $\mathrm{B}_{10} \mathrm{R}_{90}$ & $19.4 \pm 1.0$ & $15.9 \pm 2.9$ & 3.4 & $7.3 \pm 1.6$ \\
\hline & $\mathrm{B}_{10} \mathrm{G}_{5} \mathrm{R}_{85}$ & $20.0 \pm 0.6$ & $17.1 \pm 2.9$ & 2.8 & $7.6 \pm 1.6$ \\
\hline & $\mathrm{B}_{12} \mathrm{G}_{20} \mathrm{R}_{68}+\mathrm{FR}$ & $19.5 \pm 0.9$ & $16.2 \pm 2.1$ & 3.3 & $7.2 \pm 1.6$ \\
\hline & $\mathrm{B}_{45} \mathrm{R}_{55}$ & $20.4 \pm 1.5$ & $18.1 \pm 2.3$ & 2.3 & $6.7 \pm 1.5$ \\
\hline \multirow[t]{6}{*}{29 Dec. } & $\mathrm{HPS}_{10}$ & $19.0 \pm 0.7$ & $11.5 \pm 3.1$ & 7.5 & $3.5 \pm 1.2$ \\
\hline & $\mathrm{HPS}_{90}$ & $19.7 \pm 1.1$ & $15.3 \pm 2.5$ & 4.4 & $7.7 \pm 1.0$ \\
\hline & $\mathrm{B}_{10} \mathrm{R}_{90}$ & $18.8 \pm 0.9$ & $14.3 \pm 2.0$ & 4.5 & $7.7 \pm 0.9$ \\
\hline & $\mathrm{B}_{10} \mathrm{G}_{5} \mathrm{R}_{85}$ & $18.8 \pm 1.5$ & $13.2 \pm 1.8$ & 5.6 & $8.7 \pm 1.1$ \\
\hline & $\mathrm{B}_{12} \mathrm{G}_{20} \mathrm{R}_{68}+\mathrm{FR}$ & $19.7 \pm 0.8$ & $14.7 \pm 1.9$ & 5.1 & $7.2 \pm 1.0$ \\
\hline & $\mathrm{B}_{45} \mathrm{R}_{55}$ & $20.7 \pm 0.8$ & $12.1 \pm 1.9$ & 8.5 & $7.2 \pm 0.9$ \\
\hline
\end{tabular}

Table 2. Means $( \pm \mathrm{SD})$ of temperature and photosynthetic daily light integral (DLI) as measured in greenhouses by aspirated thermocouples, infrared sensors, and quantum sensors from transplant to flowering under ambient radiation, with supplemental radiation treatments delivered by high-pressure sodium (HPS) lamps or light-emitting diodes (LEDs). For the LED treatments (all delivered at $90 \mu \mathrm{mol} \cdot \mathrm{m}^{-2} \cdot \mathrm{s}^{-1}$ ), subscript values that follow each waveband of blue (B; $400-$ $500 \mathrm{~nm}$ ), green (G; 500-600 nm), red (R; 600-700 nm), and far red (FR; 700-800 nm) radiation indicate their percentages. Numbers in subscript after HPS treatments denote their intensity $\left(\mu \mathrm{mol} \cdot \mathrm{m}^{-2} \cdot \mathrm{s}^{-1}\right)$.

\begin{tabular}{|c|c|c|c|c|c|}
\hline Transplant date & $\begin{array}{c}\text { Supplemental } \\
\text { radiation treatment }\end{array}$ & Daytime air temp $\left({ }^{\circ} \mathrm{C}\right)$ & Daytime canopy temp $\left({ }^{\circ} \mathrm{C}\right)$ & Air-canopy temp $\left({ }^{\circ} \mathrm{C}\right)$ & $\operatorname{DLI}\left(\mathrm{mol} \cdot \mathrm{m}^{-2} \cdot \mathrm{d}^{-1}\right)$ \\
\hline \multirow[t]{6}{*}{25 Nov. } & $\mathrm{HPS}_{10}$ & $19.0 \pm 0.7$ & $13.3 \pm 1.1$ & 5.6 & $3.5 \pm 1.4$ \\
\hline & $\mathrm{HPS}_{90}$ & $19.8 \pm 1.3$ & $16.7 \pm 3.1$ & 3.2 & $7.6 \pm 1.1$ \\
\hline & $\mathrm{B}_{10} \mathrm{R}_{90}$ & $19.2 \pm 1.0$ & $16.0 \pm 2.8$ & 3.1 & $7.6 \pm 1.1$ \\
\hline & $\mathrm{B}_{10} \mathrm{G}_{5} \mathrm{R}_{85}$ & $18.9 \pm 0.9$ & $15.4 \pm 3.4$ & 3.5 & $8.4 \pm 1.5$ \\
\hline & $\mathrm{B}_{12} \mathrm{G}_{20} \mathrm{R}_{68}+\mathrm{FR}$ & $19.8 \pm 0.9$ & $16.2 \pm 2.7$ & 3.6 & $7.4 \pm 1.1$ \\
\hline & $\mathrm{B}_{45} \mathrm{R}_{55}$ & $20.6 \pm 0.8$ & $13.7 \pm 3.1$ & 6.9 & $7.3 \pm 1.0$ \\
\hline \multirow[t]{6}{*}{20 Jan. } & $\mathrm{HPS}_{10}$ & $19.8 \pm 1.4$ & $15.2 \pm 2.9$ & 4.6 & $5.6 \pm 2.3$ \\
\hline & $\mathrm{HPS}_{90}$ & $20.7 \pm 1.7$ & $21.1 \pm 5.2$ & -0.4 & $9.1 \pm 1.9$ \\
\hline & $\mathrm{B}_{10} \mathrm{R}_{90}$ & $19.7 \pm 1.2$ & $18.9 \pm 3.4$ & 0.7 & $9.6 \pm 1.9$ \\
\hline & $\mathrm{B}_{10} \mathrm{G}_{5} \mathrm{R}_{85}$ & $19.0 \pm 1.2$ & $16.6 \pm 4.2$ & 2.4 & $10.4 \pm 1.7$ \\
\hline & $\mathrm{B}_{12} \mathrm{G}_{20} \mathrm{R}_{68}+\mathrm{FR}$ & $20.4 \pm 1.2$ & $17.8 \pm 4.2$ & 2.6 & $9.3 \pm 1.9$ \\
\hline & $\mathrm{B}_{45} \mathrm{R}_{55}$ & $21.4 \pm 1.0$ & $14.7 \pm 3.7$ & 6.7 & $9.2 \pm 1.8$ \\
\hline
\end{tabular}

seedling phase and $5 \mathrm{~cm}$ above one plant during the transplant phase and oriented downward at a $45^{\circ}$ angle. The $P P F D$ was measured in each treatment at bench height and recorded by a quantum sensor (LI190SA; LI-COR, Lincoln, NE). Whitewash (Kool Ray Classic; Continental Products Co., Euclid, $\mathrm{OH}$ ) was applied on the glassglazed greenhouse exterior to decrease the intensity (by $\approx 20 \%$ ) midway through the second replication. Environmental conditions in each section were monitored and logged with a data logger (CR-10; Campbell Scientific, Logan, UT) every $10 \mathrm{~s}$, and hourly averages were recorded. Environmental data during the seedling and transplant phases are reported in Tables 1 and 2, respectively.

Seedling measurements and transplant. After $14-26 \mathrm{~d}$ of radiation treatments (depending on species and seasonal conditions), eight seedlings from each block, 16 seedlings in total, were sampled at random, excluding those in edge rows, and the following measurements were made: leaf area [using a leaf area meter (LI-3000; LI-COR)], leaf number (those $\geq 1 \mathrm{~cm}^{2}$ ), and plant height (from substrate surface). Shoots were cut at the medium surface, and roots, separated from the medium in a washbasin, were then

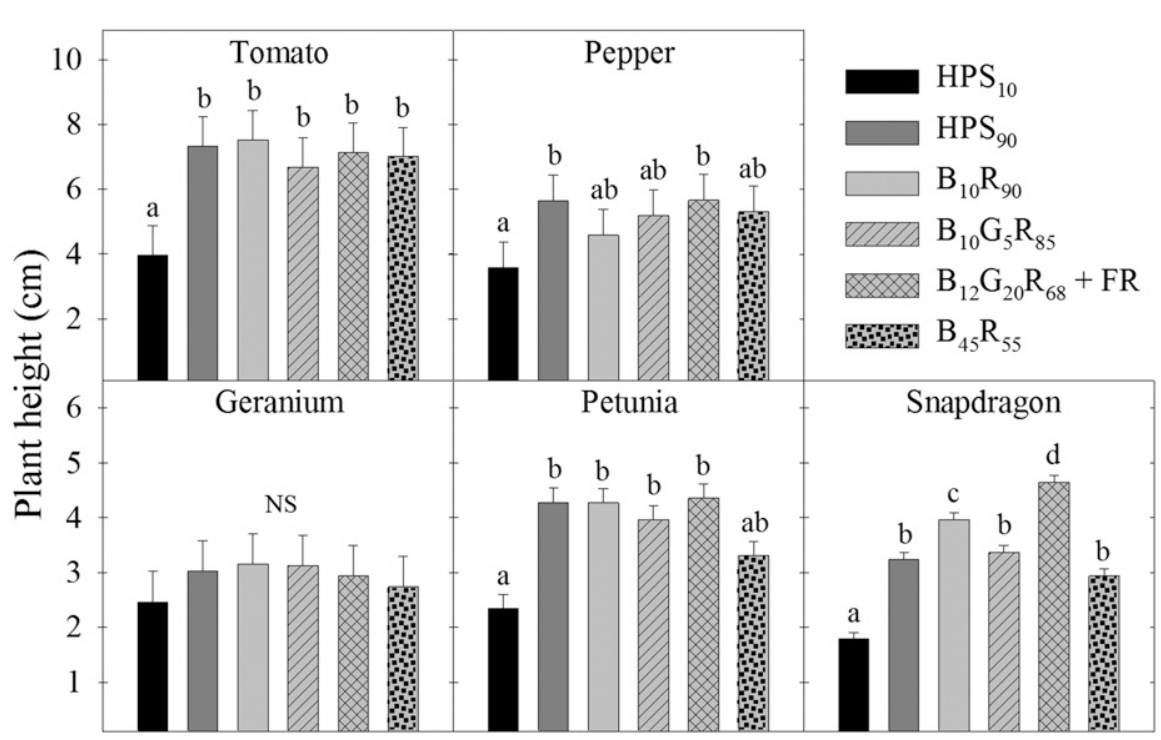

Supplemental lighting treatment

Fig. 2. Plant height of five seedling crops grown under ambient greenhouse radiation and supplemental lighting from two high-pressure sodium (HPS) or four light-emitting diode (LED) treatments delivering different percentages of blue (B; 400-500 nm), green (G; 500-600 nm), red (R; 600$700 \mathrm{~nm}$ ), and far red (FR; 700-800 nm) radiation. All treatments delivered a photosynthetic photon flux density of $90 \mu \mathrm{mol} \cdot \mathrm{m}^{-2} \cdot \mathrm{s}^{-1}$, except HPS $\mathrm{H}_{10}$, which delivered $10 \mu \mathrm{mol} \cdot \mathrm{m}^{-2} \cdot \mathrm{s}^{-1}$. For the LED treatments, subscript values denote the waveband proportions. Ns = nonsignificant; means sharing a letter are not statistically different by Tukey's honest significant difference test at $P \leq 0.05$. Error bars indicate standard error. 

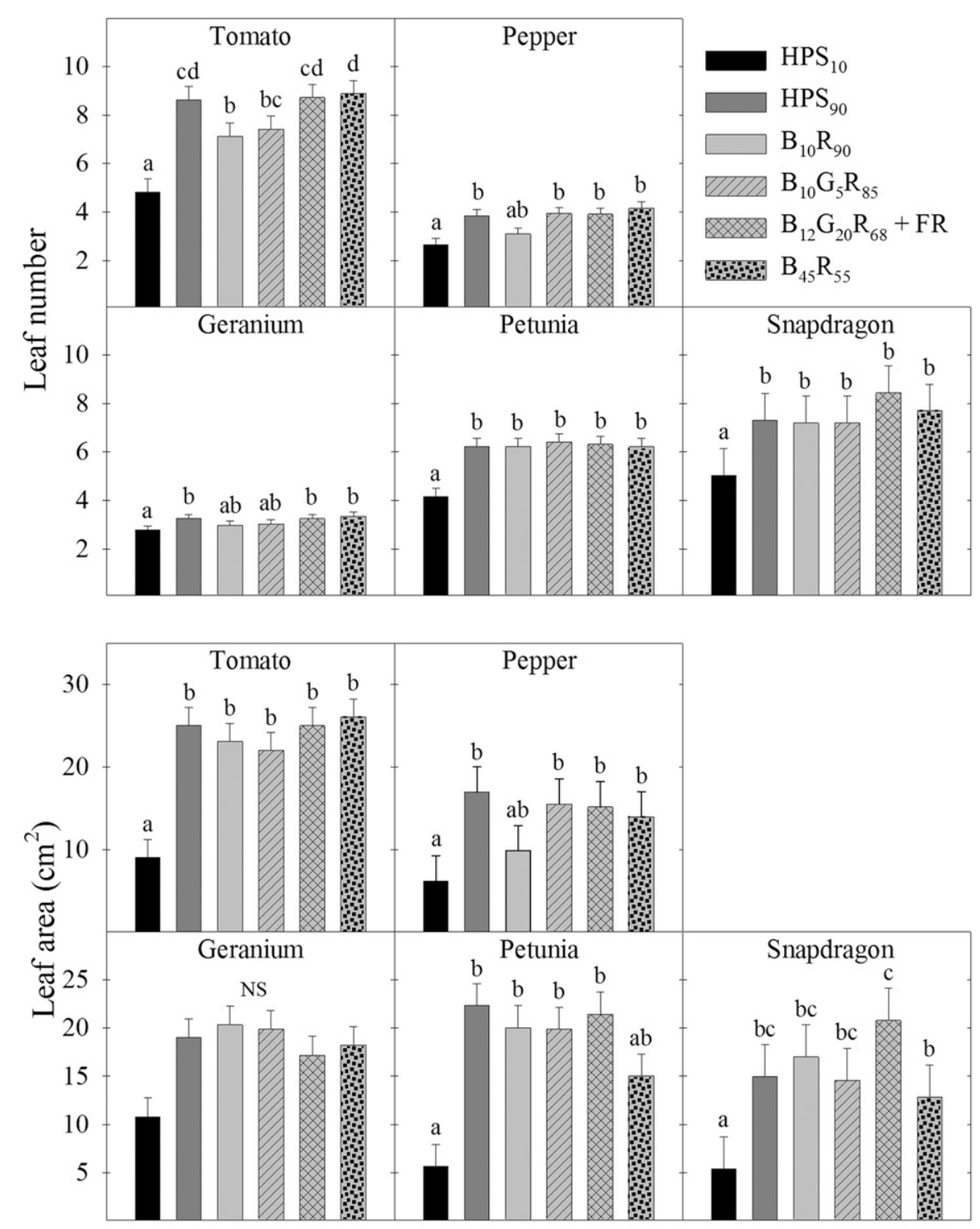

Supplemental lighting treatment

Fig. 3. The leaf number and leaf area of five seedling crops grown under ambient greenhouse radiation and supplemental radiation from two high-pressure sodium (HPS) or four light-emitting diode treatments delivering different percentages of blue (B; 400-500 nm), green (G; 500-600 nm), red (R; 600-700 nm), and far red (FR; 700-800 nm) radiation. See caption for Fig. 2 for treatment and statistical information.

placed in paper envelopes and into a drying oven (NAPCO 630; NAPCO Scientific Co., Tualatin, OR) at $80{ }^{\circ} \mathrm{C}$ for at least $48 \mathrm{~h}$ then measured for shoot and root dry weight. From the remaining seedlings, 10 each (five from each block) of geranium, petunia, and snapdragon from each treatment were transplanted into $10-\mathrm{cm}$ pots containing $70 \%$ peatmoss, $21 \%$ perlite, and $9 \%$ vermiculite (SUREMIX; Michigan Grower Products Inc., Galesburg, MI) and returned to their respective SR treatment. Pots were irrigated with line-fed water-soluble fertilizer providing (in mg. $\mathrm{L}^{-1}$ ) $125 \mathrm{~N}, 12 \mathrm{P}, 100 \mathrm{~K}, 65$ $\mathrm{Ca}, 12 \mathrm{Mg}, 1 \mathrm{Fe}$ and $\mathrm{Cu}, 0.5 \mathrm{Mn}$ and $\mathrm{Zn}, 0.3$ $\mathrm{B}$, and 0.1 Mo (MSU RO Water Special; GreenCare Fertilizers, Inc.) as necessary and rotated positionally every $2 \mathrm{~d}$. Date of first open flower or inflorescence, height at first

\section{Results}

Seedling height. At transplant, seedlings of petunia, snapdragon, tomato, and pepper were shorter when grown under the $\mathrm{HPS}_{10}$ treatment compared with those grown under HPS $_{90}$; height of geranium seedlings was similar under all treatments (Fig. 2). Tomato, pepper, and petunia seedlings grown under any $90 \mu \mathrm{mol} \cdot \mathrm{m}^{-2} \cdot \mathrm{s}^{-1}$ SR treatment were similar in height; however, petunia seedlings grown under $\mathrm{B}_{45} \mathrm{R}_{55}$ were similar in height to those grown under $\mathrm{HPS}_{10}$ SR. Snapdragon seedlings grown under $\mathrm{B}_{12} \mathrm{G}_{20} \mathrm{R}_{68}+\mathrm{FR}$ were the tallest among treatments, followed by those grown under $\mathrm{B}_{10} \mathrm{R}_{90}$, and those under the remaining $90 \mu \mathrm{mol} \cdot \mathrm{m}^{-2} \cdot \mathrm{s}^{-1}$ treatments were similar in height.

Leaf number and leaf area of seedlings. Tomato seedlings grown under $\mathrm{B}_{45} \mathrm{R}_{55}$ had more leaves at transplant than those grown under $\mathrm{B}_{10} \mathrm{R}_{90}, \mathrm{~B}_{10} \mathrm{G}_{5} \mathrm{R}_{85}$, and $\mathrm{HPS}_{10}$ $\mathrm{SR}$, whereas those under each of the 90 $\mu \mathrm{mol} \cdot \mathrm{m}^{-2} \cdot \mathrm{s}^{-1}$ SR treatments had more leaves than those grown under $\mathrm{HPS}_{10}$ (Fig. 3). There were no other differences in leaf number among the other crops grown under the $90 \mu \mathrm{mol} \cdot \mathrm{m}^{-2} \cdot \mathrm{s}^{-1} \mathrm{SR}$ treatments. The total leaf area for all crops studied was similar among the $90 \mu \mathrm{mol} \cdot \mathrm{m}^{-2} \cdot \mathrm{s}^{-1}$ SR treatments except for snapdragon seedlings, in which those grown under $\mathrm{B}_{45} \mathrm{R}_{55}$ had $37 \%$ less leaf area than seedlings grown under $\mathrm{B}_{12} \mathrm{G}_{20} \mathrm{R}_{68}+$ FR. Leaf area under $\mathrm{HPS}_{10}$ SR was $63 \%, 64 \%$, $64 \%$, and $75 \%$ less than that of seedlings grown under $\mathrm{HPS}_{90} \mathrm{SR}$ in pepper, tomato, snapdragon, and petunia, respectively. There were no differences in average leaf area (the quotient of total leaf area and average leaf number) among $90 \mu \mathrm{mol} \cdot \mathrm{m}^{-2} \cdot \mathrm{s}^{-1}$ SR treatments (data not presented).

Seedling dry weights. In all crops tested, dry shoot weight was significantly less in seedlings grown under the HPS ${ }_{10}$ treatment than those grown under the LED and HPS $_{90}$ SR treatments (Fig. 4). Seedlings grown under $\mathrm{HPS}_{10}$ accumulated 53\%, 68\%, 69\%, $75 \%$, and $79 \%$ less dry weight in geranium, pepper, tomato, petunia, and snapdragon, respectively, compared with those grown under $\mathrm{HPS}_{90}$. Among the $90 \mu \mathrm{mol} \cdot \mathrm{m}^{-2} \cdot \mathrm{s}^{-1}$ SR treatments, only pepper seedlings exhibited a difference in dry weight among LED SR treatments: those under $\mathrm{B}_{10} \mathrm{R}_{90} \mathrm{SR}$ accumulated less dry matter than seedlings grown under $\mathrm{HPS}_{90} \mathrm{SR}$.

Root dry weights of tomato, petunia, pepper, and snapdragon were $40 \%, 57 \%$, $68 \%$, and $76 \%$ less, respectively, when grown under $\mathrm{HPS}_{10}$ than those grown under HPS $_{90}$ SR. Tomato seedling root weight was greater under $\mathrm{HPS}_{90} \mathrm{SR}$ and $\mathrm{B}_{12} \mathrm{G}_{20} \mathrm{R}_{68}+\mathrm{FR}$ LED SR compared with that in the $\mathrm{HPS}_{10}$ treatment, whereas weights under the remaining LED SR treatments were similar. In all crops tested, there were no differences in dry root weights among the $90 \mu \mathrm{mol} \cdot \mathrm{m}^{-2} \cdot \mathrm{s}^{-1}$ SR treatments.

Days to first flower. Seedlings grown under $\mathrm{HPS}_{10}$ continuously (during the seedling and transplant phases) took the longest to 

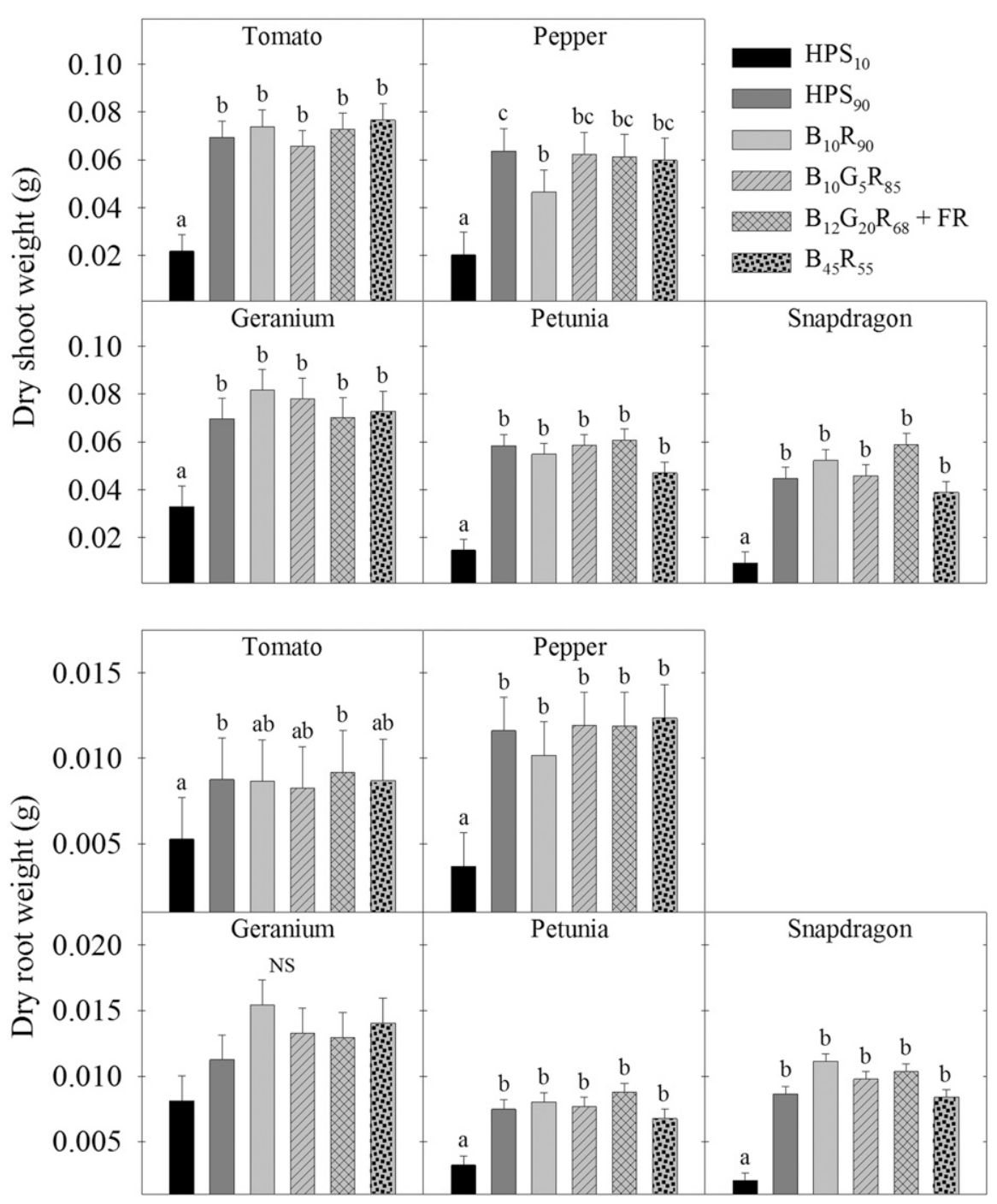

Supplemental lighting treatment

Fig. 4. Dry shoot and root weights of five seedling crops grown under ambient greenhouse radiation and supplemental radiation from two high-pressure sodium (HPS) or four light-emitting diode treatments delivering different percentages of blue (B; 400-500 nm), green (G; 500-600 nm), red (R; 600-700 nm), and far red (FR; 700-800 $\mathrm{nm}$ ) radiation. See caption for Fig. 2 for treatment and statistical information.

flower (Fig. 5). On average, snapdragon, petunia, and geranium under the $\mathrm{HPS}_{10}$ treatment flowered 19, 23, and 24 d later than those grown under the $\mathrm{HPS}_{90}$ treatment. Petunia transplants grown under $90 \mu \mathrm{mol} \cdot \mathrm{m}^{-2} \cdot \mathrm{s}^{-1}$ SR treatments took a similar number of days to flower, whereas among LED SR treatments, snapdragon flowered earliest when grown under the $\mathrm{B}_{12} \mathrm{G}_{20} \mathrm{R}_{68}+\mathrm{FR}$ treatment. Geranium transplants grown under $\mathrm{B}_{10} \mathrm{R}_{90}$ and $\mathrm{B}_{10} \mathrm{G}_{5} \mathrm{R}_{85}$ took longer to flower than those grown under $B_{12} G_{20} R_{68}+F R$ and $B_{45} R_{55}$, but flowering time was similar to that of plants grown under $\mathrm{HPS}_{90}$.

Plant height at first flower. Snapdragon plants were of similar height at flowering under all SR treatments. Petunia plants grown under $\mathrm{HPS}_{10}$ were taller at first flower than those grown under $\mathrm{HPS}_{90}, \mathrm{~B}_{10} \mathrm{R}_{90}$, and $\mathrm{B}_{45} \mathrm{R}_{55}$, but their height was similar to that of those grown under $\mathrm{B}_{10} \mathrm{G}_{5} \mathrm{R}_{85}$ and $\mathrm{B}_{12} \mathrm{G}_{20} \mathrm{R}_{68}+\mathrm{FR}$. treatment for which the plant inflorescence number was similar to that of those grown under $\mathrm{HPS}_{10}$

\section{Discussion}

One of our objectives was to determine whether SR that emitted a relatively high percentage $(45 \%)$ of $B$ radiation would inhibit extension growth of seedlings. Previously, we observed little or no effect of radiation quality of SR treatments on seedling growth and morphology when SR emitted $10 \%$ to $20 \% \mathrm{~B}$ radiation (Poel and Runkle, 2017). Blue radiation can suppress stem extension and leaf expansion through a cryptochrome-mediated pathway altering gene expression (Folta and Childers, 2008) and perhaps through other $\mathrm{B}$ radiationmediated photoreceptors. For example, Wollaeger and Runkle (2015) grew seedlings of impatiens (Impatiens walleriana), salvia (Salvia splendens), petunia, and tomato under LED SSR with six B:R ratios (from 100:0 to $0: 100)$, and as little as $10 \mu \mathrm{mol} \cdot \mathrm{m}^{-2} \cdot \mathrm{s}^{-1}$ of $\mathrm{B}$ radiation $(6.25 \%$ of the $P P F D)$ inhibited extension growth, whereas cryptochrome receptors were likely saturated with B radiation at $40 \mu \mathrm{mol} \cdot \mathrm{m}^{-2} \cdot \mathrm{s}^{-1}$ because plants receiving more than $25 \% \mathrm{~B}$ radiation were similar in height.

Despite the increased ratio of $\mathrm{B}$ radiation in the $\mathrm{B}_{45} \mathrm{R}_{55}$ treatment, there were few differences or consistent responses in leaf expansion and plant height under the 90 $\mu \mathrm{mol} \cdot \mathrm{m}^{-2} \cdot \mathrm{s}^{-1}$ treatments. Snapdragon seedlings grown under $\mathrm{B}_{45} \mathrm{R}_{55}$ were $26 \%$ and $37 \%$ shorter than those grown under $B_{10} R_{90}$ and $\mathrm{B}_{12} \mathrm{G}_{20} \mathrm{R}_{68}+\mathrm{FR}$, respectively; however, the addition of FR radiation may be a confounding factor in this second comparison. There were no differences in plant height or leaf area in the other four species tested among the $90 \mu \mathrm{mol} \cdot \mathrm{m}^{-2} \cdot \mathrm{s}^{-1}$ treatments. A similar lack of response in stem elongation and leaf expansion was reported under SR with $0 \%$ to $16 \%$ B radiation delivered with $\mathrm{R}$ radiation to tomato (Hernandez and Kubota, 2012), and when cucumber ( $\mathrm{CuCu}$ mis sativus) seedlings were grown under a relatively high DLI $\left(16.2 \mathrm{~mol} \cdot \mathrm{m}^{-2} \cdot \mathrm{d}^{-1}\right)$ (Hernandez and Kubota, 2014). By contrast, seedlings of snapdragon, vinca (Catharanthus roseus), impatiens, geranium, petunia, and marigold (Tagetes patula) were more compact when grown under LED SR delivering $15 \%$ and $30 \% \mathrm{~B}$ radiation with $\mathrm{R}$ radiation compared with those grown under HPS, but there were no differences in plant height between the two $\mathrm{B}+\mathrm{R}$ LED SR treatments (Randall and Lopez, 2014). The lack of a clear B radiation response in our and other SR studies could be attributed to the saturation of $\mathrm{B}$ radiation-absorbing photoreceptors (e.g., cryptochrome) from background ambient sunlight. All plants received a DLI of $\approx 3-5 \mathrm{~mol} \cdot \mathrm{m}^{-2} \cdot \mathrm{d}^{-1}$ from sunlight (Tables 1 and 2), which equates to $\approx 0.7-1.2 \mathrm{~mol} \cdot \mathrm{m}^{-2} \cdot \mathrm{d}^{-1}$ of $\mathrm{B}$ radiation, potentially enough to saturate $\mathrm{B}$ radiation photoreceptors across all treatments. 


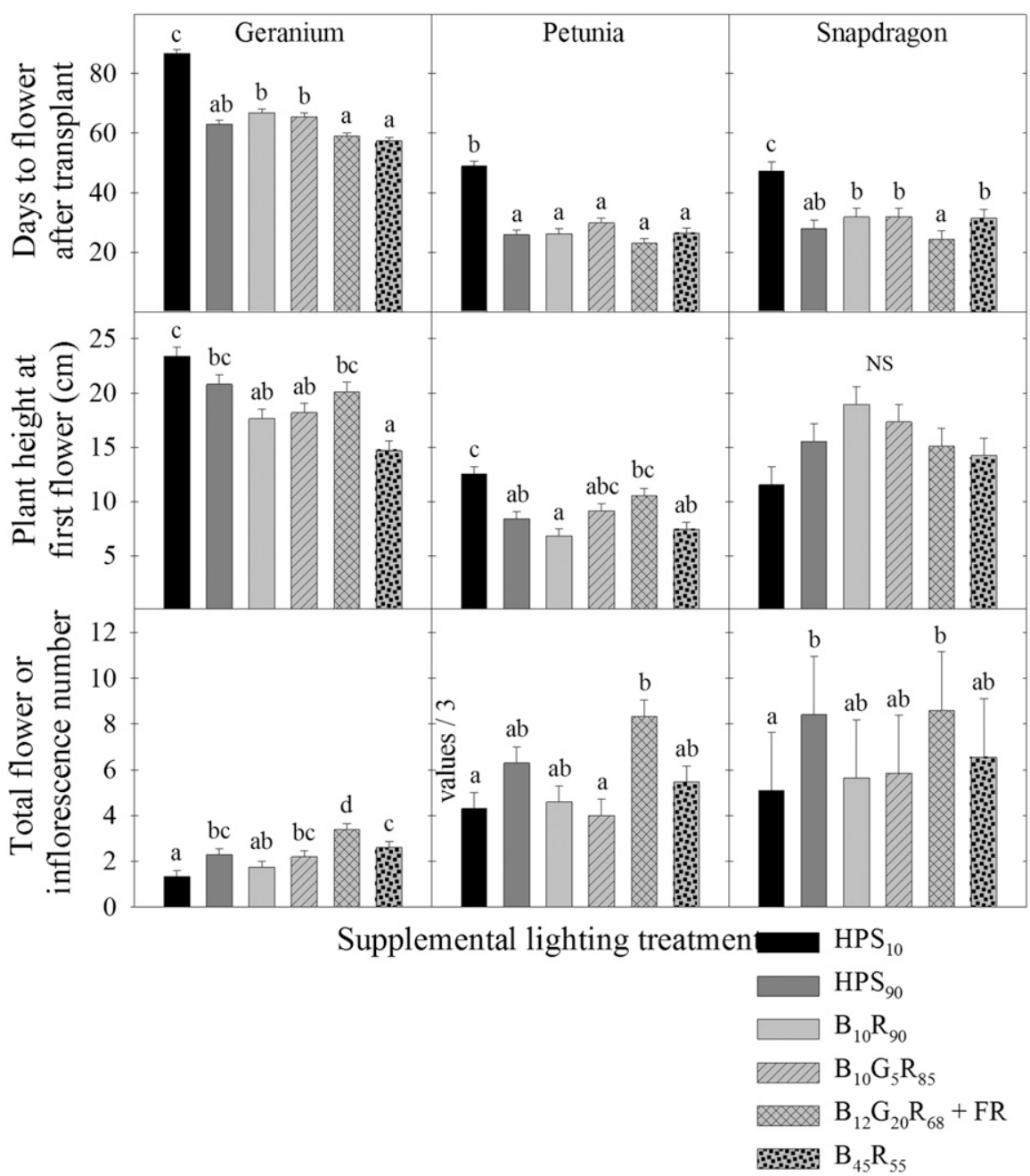

Fig. 5. Days to flower after transplant, plant height at first flower, and total flower or inflorescence number of three seedling crops grown under ambient greenhouse radiation and supplemental radiation from two high-pressure sodium (HPS) or four light-emitting diode treatments delivering different percentages of blue $(B ; 400-500 \mathrm{~nm})$, green $(\mathrm{G} ; 500-600 \mathrm{~nm})$, red $(\mathrm{R} ; 600-700 \mathrm{~nm})$, and far red (FR; 700-800 nm) radiation. For petunia, the $y$ axis values for flower number are divided by three, as noted. See caption for Fig. 2 for treatment and statistical information.

We were also interested in the effects of SR treatments (especially the different percentages of B radiation) on plant growth after transplant. After 12 weeks under SR, geranium plants grown under $\mathrm{B}_{45} \mathrm{R}_{55}$ were $27 \%$ shorter at flowering than those grown under $\mathrm{HPS}_{90}$, but were similar to those under the other two LED treatments without FR radiation. Snapdragon were of the same height at flowering under all SR treatments, and petunia plants were generally similar under the $90 \mu \mathrm{mol} \cdot \mathrm{m}^{-2} \cdot \mathrm{s}^{-1} \mathrm{SR}$ treatments. In another SR experiment, shoot length of three poinsettia (Euphorbia pulcherrima) cultivars after 12 weeks was reduced by $20 \%$ to $34 \%$ under $20 \% \mathrm{~B}+80 \% \mathrm{R}$ radiation from LEDs compared with that under HPS lamps (Islam et al., 2012). The authors attributed the reduced plant height to the increased $\mathrm{B}$ radiation in the LED treatment and cryptochrome-mediated elongation suppression. The lack of consistent plant height effects in petunia and snapdragon, but shorter geranium at first flower, under the $\mathrm{B}_{45} \mathrm{R}_{55}$ treatment could be attributed to the increased time under the SR treatments; geraniums flowered in an average of $66 \mathrm{~d}$ after transplant, whereas petunia and snapdragon flowered in half that time and therefore had shorter exposure to the SR treatments. It is also possible that geranium is more sensitive to B radiation effects, and additional studies focusing on spectral sensitivity compared with other species are needed.

A second experimental objective was to investigate the effect of adding FR to SR on seedling extension growth and subsequent flowering. Through manipulation of the phytochrome photoreceptors, FR radiation can regulate plant growth and flowering. There is generally an inverse linear relationship of PPE to extension growth; however, specific responses to the R:FR ratio vary among species and depend on the inclusion of other wavelengths (Runkle and Heins, 2001). In our study, snapdragon seedlings grown under the FR-emitting SR treatment $(\mathrm{PPE}=0.84$ ) were tallest among treatments and had a greater leaf area than those grown under $\mathrm{B}_{45} \mathrm{R}_{55}(\mathrm{PPE}=0.86)$. Park and Runkle (2017) reported up to a $53 \%$ increase in snapdragon seedling height and $41 \%$ increase in leaf area at transplant as PPE decreased from 0.88 to 0.69 in SSR treatments when the intensity of $\mathrm{B}$ radiation was constant. Although the SR treatments had slightly different PPEs, morphological responses could be confounded by the different intensities of $B, G$, and $R$ radiation delivered in each treatment. The effects of SR on plant height at flowering were inconsistent although plants grown under the $\mathrm{B}_{12} \mathrm{G}_{20} \mathrm{R}_{68}+\mathrm{FR}$ treatment were always at least as tall as those grown under the other LED SR treatments. The commercial fixtures used in this experiment did not have adjustable spectra; therefore, further testing with fixed ratios of $\mathrm{B}, \mathrm{G}$, and $\mathrm{R}$ radiation among treatments would be needed to isolate the effects from added FR radiation.

In the production of ornamental transplants, producing compact seedlings is a common objective, which can be achieved with radiation with a high $\mathrm{R}: \mathrm{FR}$ ratio, but a high $\mathrm{R}$ : FR ratio can potentially delay flower initiation and development in some long-day plants (Runkle and Heins, 2001). Snapdragon grown under the $\mathrm{B}_{12} \mathrm{G}_{20} \mathrm{R}_{68}+\mathrm{FR}$ treatment flowered $8 \mathrm{~d}$ earlier than those under the remaining LED SR treatments although time to flower was similar to that of those under the HPS $_{90}$ treatment. Under an FR-radiationintercepting filter creating a high R:FR, flower initiation was delayed in campanula (Campanula carpatica) and coreopsis ( $\mathrm{Co}$ reopsis $\times$ grandiflora), and flower development was inhibited in viola (Viola $\times$ wittrockiana) (Runkle and Heins, 2001). Runkle and Heins (2003) were successful in promoting flowering of viola by adding FR radiation inside an FRdeficient environment throughout the photoperiod, or for $4 \mathrm{~h}$, at the end of the photoperiod or during the middle of the 15-h night. However, treatments that promoted flowering also promoted extension growth. More experimentation is required to determine the usefulness of including FR radiation in SR on plant growth and development, perhaps with higher FR intensities or alteration of the timing at which it is delivered.

When the ambient solar DLI is low (e.g., $\left.<8 \mathrm{~mol} \cdot \mathrm{m}^{-2} \cdot \mathrm{d}^{-1}\right)$, SR can be used in greenhouses to increase DLI and thus quality parameters of seedlings (Pramuk and Runkle, 2005). The DLI under the HPS 10 treatment was $\approx 3-4 \mathrm{~mol} \cdot \mathrm{m}^{-2} \cdot \mathrm{d}^{-1}$ lower than under the $90 \mu \mathrm{mol} \cdot \mathrm{m}^{-2} \cdot \mathrm{s}^{-1}$ SR treatments, whereas the photoperiod was the same $(16 \mathrm{~h})$. In previous SR experiments that increased DLI during the seedling phase, growth (as measured by dry mass accumulation), stem caliper, and leaf area increased (Hernandez and Kubota, 2014; Randall and Lopez, 2015). For example, Hernandez and Kubota (2014) grew cucumber plants in a greenhouse with and without SR at a PPFD of $54 \mu \mathrm{mol} \cdot \mathrm{m}^{-2} \cdot \mathrm{s}^{-1}$ from LEDs at three different $\mathrm{R}$ and $\mathrm{B}$ radiation ratios at two ambient DLIs, 5.2 and $16.2 \mathrm{~mol} \cdot \mathrm{m}^{-2} \cdot \mathrm{d}^{-1}$. At both DLIs, the 
seedlings grown with SR had a greater dry and fresh weight, leaf number, leaf area, and stem diameter. Similarly, in our experiment, seedlings of each species had a greater dry shoot weight when grown under the 90 $\mu \mathrm{mol} \cdot \mathrm{m}^{-2} \cdot \mathrm{s}^{-1} \mathrm{SR}$ treatments. Root dry weight, leaf area, and leaf number were also greater for three of five species grown under SR.

Plants can exhibit shade-avoidance responses, such as increases in extension growth, in response to decreases in the R:FR ratio, the $P P F D$, or both (Ballare et al., 1991; Smith, 1982). Hernandez and Kubota (2014) reported an increase in hypocotyl length for seedlings grown without SR, but in this current study, seedlings grown under the lower DLI were of the same height as or shorter than those grown under the 90 $\mu \mathrm{mol} \cdot \mathrm{m}^{-2} \cdot \mathrm{s}^{-1}$ SR treatments. Similarly, seedling height of five species was similar or shorter under ambient radiation compared with that of those grown under SR from HPS lamps or LEDs (Randall and Lopez, 2015). However, in a separate study, stem length of impatiens and salvia decreased as DLI increased, whereas the opposite occurred in marigold and celosia [Celosia argentea var. plumosa (Pramuk and Runkle, 2005)]. We attribute the shorter seedlings in our study to the development of fewer nodes at transplant. Compared with those grown under $\mathrm{HPS}_{90}$, seedlings of pepper, tomato, petunia, and snapdragon grown under HPS $_{10}$ were $37 \%$, $44 \%, 46 \%$, and $62 \%$ shorter and had $31 \%$, $44 \%, 33 \%$, and $31 \%$ fewer nodes, respectively. Therefore, a paradigm exists that although plant height increases under lowradiation conditions, plants may be shorter than those grown under higher radiation because they are less mature.

Providing an increased DLI to plants during the finishing stage can decrease time to flower, increase finished plant quality, or both in many species (Blanchard et al., 2011). Therefore, we postulated that time to flower would be reduced by providing SR during the transplant and finishing phases. Faust et al. (2005) reported that increasing DLI from 5 to $19 \mathrm{~mol} \cdot \mathrm{m}^{-2} \cdot \mathrm{d}^{-1}$ during the transplant phase decreased days to flower for marigold, petunia, salvia, and zinnia. In our experiment, all species tested flowered earlier under the high-intensity SR treatments. Similarly, Sams et al. (2016) noted an increase in the inflorescence number on marigold grown under SR that added $8.6 \mathrm{~mol} \cdot \mathrm{m}^{-2} \cdot \mathrm{d}^{-1}$ (from HPS lamps or LEDs) to a solar DLI of 11.5 $\mathrm{mol} \cdot \mathrm{m}^{-2} \cdot \mathrm{d}^{-1}$ compared with those grown without SR. We observed an increase in the inflorescence number in geranium under four SR treatments compared with those grown under $\mathrm{HPS}_{10}$, whereas flower and inflorescence numbers in petunia and snapdragon showed inconsistent responses to DLI. However, more radiation does not necessarily increase the flower number at first flowering. Although an increased DLI decreased time to flower, there was also a decrease in the total flower number at first flowering (Pramuk and Runkle, 2005). Plants that take longer to flower have a longer vegetative phase and therefore have more time to harvest radiation and accumulate carbohydrates for flower production. A similar response in flower production occurred when plants were grown at lower temperatures; time to flower and the flower number at first flowered generally increased as the average daily temperature decreased (Vaid et al., 2014).

Even with an increased percentage of B radiation in our SR treatments, we were not able to elicit consistent responses in seedling or transplant growth and morphology. Growing geraniums for their complete life cycle under $B_{45} R_{55} S R$ (with a higher percentage of $B$ radiation) could be an effective tool for height control, depending on the DLI conditions. The inclusion of FR radiation with SR also showed inconsistent responses, but it did accelerate flowering of snapdragon and may have a similar effect on other long-day crops when the natural photoperiod is short. Research with SR treatments with more extreme spectral differences in B and FR radiation or a range of ambient solar DLIs, and perhaps other wavebands, is needed to further explore the potential of how SR can be used to achieve more compact growth and early flowering of ornamental crops.

\section{Literature Cited}

Ahmad, M., N. Grancher, M. Heil, R.C. Black, B. Giovani, P. Galland, and D. Lardemer. 2002. Action spectrum for cryptochrome-dependent hypocotyl growth inhibition in Arabidopsis. Plant Physiol. 129:774-785.

Ballaré, C.M., A.L. Scopel, and R.A. Sánchez. 1991. Photocontrol of stem elongation in plant neighbourhoods: Effects of photon fluence rate under natural conditions of radiation. Plant Cell Environ. 50:522-529.

Blanchard, M.G., E.S. Runkle, and P.R. Fisher 2011. Modeling plant morphology and development of petunia in response to temperature and photosynthetic daily light integral. Sci. Hort. 129:313-320.

Bourget, C.M. 2008. An introduction to lightemitting diodes. HortScience 43:1944-1946.

Brown, C.S., A.C. Schuerger, and J.C. Sager. 1995. Growth and photomorphogenesis of pepper plants under red light-emitting diodes with supplemental blue or far-red lighting. J. Amer. Soc. Hort. Sci. 120:808-813.

Bula, R.J., R.C. Morrow, T.W. Tibbitts, D.J. Barta, R.W. Ignatius, and T.S. Martin. 1991. Lightemitting diodes as a radiation source for plants. HortScience 26:203-205.

Chia, P.L. and C. Kubota. 2010. End-of-day far-red light quality and dose requirements for tomato rootstock hypocotyl elongation. HortScience 45:1501-1506.

Faust, J.E., V. Holcombe, N.C. Rajapakse, and D.R. Layne. 2005. The effect of daily light integral on bedding plant growth and flowering. HortScience 40:645-649.

Folta, K.M. and S.D. Carvalho. 2015. Photoreceptors and control of horticultural plant traits. HortScience 50:1274-1280.

Folta, K.M. and K.S. Childers. 2008. Light as a growth regulator: Controlling plant biology with narrow-bandwidth solid-state lighting systems. HortScience 43:1957-1964.

Franklin, K. and G. Whitelam. 2005. Phytochromes and shade-avoidance responses in plants. Ann. Bot. 96:169-175.
Goins, G.D., N.C. Yorio, M.M. Sanwo, and C.S. Brown. 1997. Photomorphogenesis, photosynthesis, and seed yield of wheat plants grown under red light-emitting diodes (LEDs) with and without supplemental blue lighting. J. Expt. Bot. 48:1407-1413.

Hernandez, R. and C. Kubota. 2012. Tomato seedling growth and morphological responses to supplemental LED lighting red:blue ratios under varied daily solar light integrals. Acta Hort. 956:187-194.

Hernandez, R. and C. Kubota. 2014. Growth and morphological response of cucumber seedlings to supplemental red and blue photon flux ratios under varied solar daily light integrals. Sci. Hort. 173:92-99.

Hoenecke, M.E., R.J. Bula, and T.W. Tibbitts. 1992. Importance of 'blue' photon levels for lettuce seedlings grown under red-lightemitting diodes. HortScience 27:427-430.

Islam, A.M., G. Kuwar, J.L. Clarke, D.R. Blystad, H.R. Gislerød, J.E. Olsen, and S. Torre. 2012. Artificial light from light emitting diodes (LEDs) with a high portion of blue light results in shorter poinsettias compared to high pressure sodium (HPS) lamps. Sci. Hort. 184:171178.

Korczynski, P.C., J. Logan, and J.E. Faust. 2002. Mapping monthly distribution of daily light integrals across the contiguous United States. HortTechnology 12:12-16.

Lopez, R.G. and E.S. Runkle. 2008. Photosynthetic daily light integral during propagation influences rooting and growth of cuttings and subsequent development of New Guinea impatiens and petunia. HortScience 43:20522059.

Meng, Q. and E.S. Runkle. 2014. Controlling flowering of photoperiodic ornamental crops with light-emitting diode lamps: A coordinated grower trial. HortTechnology 24:702-711.

Mitchell, C.A., M.P. Dzakovich, C. Gomez, R. Lopez, J.F. Burr, R. Hernaìndez, C. Kubota, C.J. Currey, Q. Meng, E.S. Runkle, C.M. Bourget, R.C. Morrow, and A.J. Both. 2015. Light-emitting diodes in horticulture. Hort. Rev. 43:1-87.

Morrow, R.C. 2008. LED lighting in horticulture. HortScience 43:1947-1950.

Park, Y. and E.S. Runkle. 2017. Far-red radiation promotes growth of seedlings by increasing leaf expansion and whole-plant net assimilation. Environ. Expt. Bot. 136:41-49.

Poel, B.R. and E.S. Runkle. 2017. Seedling growth is similar under supplemental greenhouse lighting from high-pressure sodium lamps or lightemitting diodes. HortScience 52:388-394.

Pramuk, L.A. and E.S. Runkle. 2005. Photosynthetic daily light integral during the seedling stage influences subsequent growth and flowering of Celosia, Impatiens, Salvia, Tagetes, and Viola. HortScience 40:1336-1339.

Randall, W.C. and R.G. Lopez. 2014. Comparisons of supplemental lighting from high-pressure sodium lamps and light-emitting diodes during bedding plant seedling production. HortScience 49:589-595.

Randall, W.C. and R.G. Lopez. 2015. Comparisons of bedding plant seedlings grown under solesource light-emitting diodes (LEDs) and greenhouse supplemental lighting from LEDs and high-pressure sodium lamps. HortScience 50:705-713.

Runkle, E.S. and R.D. Heins. 2001. Specific functions of red, far red and blue light in flowering and stem extension of long-day plants. J. Amer. Soc. Hort. Sci. 126:275-282. 
Runkle, E.S. and R.D. Heins. 2003. Photocontrol and flowering and extension growth in the long-day plant pansy. J. Amer. Soc. Hort. Sci. 128:479-485.

Sager, J.C., W.O. Smith, J.L. Edwards, and K.L. Cyr. 1988. Photosynthetic efficiency and phytochrome photoequilibria determination using spectral data. Trans. Amer. Soc. Agr. Eng. 31:1882-1889.

Sams, C.E., D. Kopsell, and R.C. Morrow. 2016. Light quality impacts on growth, flowering, mineral uptake and petal pigmentation of marigold. Acta Hort. 1134:139-146.
Smith, H. 1982. Light quality, photoperception, and plant strategy. Annu. Rev. Plant Physiol. 33:481-518

Tripathy, B.C. and C.S. Brown. 1995. Root-shoot interaction in the greening of wheat seedlings grown under red light. Plant Physiol. 107:407-411.

Vaid, T.M., E.S. Runkle, and J.M. Frantz. 2014. Mean daily temperature regulates plant quality attributes of annual ornamental plants. HortScience 49:574-580.

Wallace, C. and A.J. Both. 2016. Evaluating operating characteristics of light sources for horticultural applications. Acta Hort. 1134:435-444.

Wollaeger, H.M. and E.S. Runkle. 2015. Growth and acclimation of impatiens, salvia, petunia, and tomato seedlings to blue and red light. HortScience 50:522-529.

Zhao, X., X. Yu, E. Foo, G.M. Symons, J. Lopez, K.T. Bendehakkalu, J. Xiang, J.L. Weller, X. Liu, and J.B. Reid. 2007. A study of gibberellin homeostasis and cryptochrome-mediated blue light inhibition of hypocotyl elongation. Plant Physiol. 145:106-118. 